\title{
Increased Angiotensinogen Production in Epicardial Adipose Tissue during Cardiac Surgery: Possible Role in a Postoperative Insulin Resistance
}

\author{
T. ROUBÍČEK ${ }^{1}$, M. DOLINKOVÁ ${ }^{1}$, J. BLÁHA ${ }^{2}$, D. HALUZÍKOVÁ ${ }^{1,3}$, L. BOŠANSKÁ ${ }^{1}$, \\ M. MRÁZ ${ }^{1}$, J. KŘEMEN ${ }^{1}$, M. HALUZÍK ${ }^{1}$
}

${ }^{1}$ Third Department of Medicine, ${ }^{2}$ Department of Anesthesia, Resuscitation and Intensive Medicine and ${ }^{3}$ Department of Sports Medicine, First Faculty of Medicine, Charles University and General University Hospital, Prague, Czech Republic

Received May 25, 2007

Accepted September 27, 2007

On-line November 30, 2007

\section{Summary}

Critical illness induces among other events production of proinflammatory cytokines that in turn interfere with insulin signaling cascade and induce insulin resistance on a postreceptor level. Recently, local renin-angiotensin system of adipose tissue has been suggested as a possible contributor to the development of insulin resistance in patients with obesity. The aim of our study was to determine local changes of the renin-angiotensin system of subcutaneous and epicardial adipose tissue during a major cardiac surgery, which may serve as a model of an acute stress potentially affecting endocrine function of adipose tissue. Ten patients undergoing elective cardiac surgery were included into the study. Blood samples and samples of subcutaneous and epicardial adipose tissue were collected at the beginning and at the end of the surgery. Blood glucose, serum insulin and adiponectin levels were measured and mRNA for angiotensinogen, angiotensin-converting enzyme and angiotensin II type 1 receptor were determined in adipose tissue samples using RT PCR. Cardiac surgery significantly increased both insulin and blood glucose levels suggesting the development of insulin resistance, while serum adiponectin levels did not change. Expression of angiotensinogen mRNA significantly increased in epicardial adipose tissue at the end of surgery relative to baseline but remained unchanged in subcutaneous adipose tissue. Fat expression of angiotensin-converting enzyme and type 1 receptor for angiotensin II were not affected by surgery. Our study suggests that increased angiotensinogen production in epicardial adipose tissue may contribute to the development of postoperative insulin resistance.

\section{Key words}

Adiponectin • Adipose tissue • Angiotensinogen • Critical illness • Insulin resistance $\bullet$ Renin-angiotensin system

\section{Corresponding author}

M. Haluzik, Third Department of Medicine, First Faculty of Medicine, Charles University, U Nemocnice 1, 128 08, Praha 2, Czech Republic. Fax: +420-224919780. E-mail: mhalu@If1.cuni.cz

\section{Introduction}

Hyperglycemia frequently occurs in critically ill patients both with and without previous history of diabetes (Shangraw et al. 1989, van den Berghe 2000, van den Berghe et al. 2006). Major patophysiological conditions underlying hyperglycemia in critical illness include enhanced hepatic gluconeogenesis, impaired insulin secretion and decreased insulin sensitivity due to anti-insulin effects of stress hormones and proinflammatory cytokines (Krinsley 2003, van den Berghe 2000). Numerous studies have documented that increased blood glucose levels worsen morbidity and mortality in critically ill patients (Butler et al. 2005, van den Berghe et al. 2001, Vanhorebeek et al. 2005); and that intensive insulin therapy aimed at maintaining euglycemia markedly improves the outcome of these patients (Krinsley 2003, van den Berghe et al. 2001, 2006). Cardiac surgery represents major stress for the 
organism and leads to secretion of stress hormones (e.g. cortisol, glucagon, growth hormone, catecholamines) and proinflammatory cytokines that in turn induce insulin resistance and hyperglycemia (van den Berghe et al. 2001). We have recently demonstrated that elective cardiac operation stimulated the production of proinflammatory cytokines such as tumor necrosis factor$\alpha$, interleukin- 6 and resistin in both epicardial and subcutaneous adipose tissue (Křemen et al. 2006). Other study reported that epicardial adipose tissue could locally interact with the adjacent myocardium and modulate the morphology and function of the heart (Iacobellis and Sharma 2007). These data suggest that endocrine production of adipose tissue may contribute to the development of insulin resistance and modulations of cardiac function not only in patients with obesity and type 2 diabetes mellitus but also in critically ill patients.

Adipose tissue produces not only proinflammatory factors and hormones (Housová et al. 2005, Housa et al. 2006, Anderlová et al. 2006) but also numerous other molecules including components of renin-angiotensin system (Jones et al. 1997, Engeli et al. 2003, Iacobellis and Sharma 2007). Renin-angiotensin system is traditionally recognized as an important regulator of systemic blood pressure, water and electrolyte homeostasis (Reid et al. 1978, Cooper et al. 2007). Production of components of renin-angiotensin system (angiotensinogen, angiotensin-converting enzyme, angiotensin II type 1 receptor) have been detected in a variety of tissues such as kidney, adrenal glands, brain, heart, and blood vessels (Cooper et al. 2007). Local renin-angiotensin system has been implicated in pathological changes of organ structure and function by modulation of gene expression, growth, fibrosis, and inflammatory response (Ganong 1994, Cooper 2004). The local renin-angiotensin system of the adipose tissue is being studied as a possible contributor to the development of systemic insulin resistance (Cooper 2004, Kim et al. 2006). Recent studies indicate that some of the components of renin-angiotensin system (e.g. angiotensin II - a metabolically active hormone derived from the cleavage of angiotensinogen) produced within the adipose tissue may directly induce insulin resistance, increase free oxygen radicals production and decrease production of leptin and adiponectin (Ferder et al. 2006, Kurata et al. 2006). Furthermore, many clinical studies have documented that treatment with angiotensinconverting enzyme inhibitors or angiotensin receptor blockers decreased the incidence of type 2 diabetes
(Hansson et al. 1999, Yusuf et al. 2000, Dahlof et al. 2002, Vermes et al. 2003, Scheen 2004). The molecular mechanism of these effects have been unknown until recently. Recent data suggest that increased local levels of angiotensin II directly interfere with insulin signaling on the postreceptor level and increase local oxidative stress in the adipose tissue (Ferder et al. 2006). Experimental studies have shown that treatment with angiotensin II type 1 receptor blockers stimulate gene expression of insulin-sensitizing adipocytokine adiponectin and increase circulating adiponectin levels in murine models of obesity (Moriuchi et al. 2007) indicating possible involvement of modulation of endocrine function of adipose tissue in the mechanism of insulin-sensitizing effect of renin-angiotensin system inhibitors.

Here we tested a hypothesis that increased production of components of renin-angiotensin system in adipose tissue is involved in the development of insulin resistance in critically ill patients. To this end we measured blood glucose, serum insulin and adiponectin levels and mRNA expression of angiotensinogen, angiotensin-converting enzyme, and receptor for angiotensin II type 1 in samples of epicardial and subcutaneous adipose tissue obtained from cardiac surgery patients at the beginning and at the end of elective operation.

\section{Methods}

\section{Study subjects}

Ten patients (six men and four women, mean age $56 \pm 14$ years, body mass index (BMI) $27 \pm 3 \mathrm{~kg} / \mathrm{m}^{2}$ ) who underwent major elective cardiac surgery (seven patients aorto-coronary bypass, three valvular plastic; duration of the surgery $4.6 \pm 1.2 \mathrm{~h}$ ) were included into the study. Clinical characteristics of the patients are shown in Table 1. One patient had type 2 diabetes on the insulin therapy, seven patients had arterial hypertension, six of these patients had been treated with antihypertensive drugs (two of them with angiotensin-converting enzyme inhibitors (ramipril), none with angiotensin receptor blockers) before the beginning of the study. Five patients had dyslipidemia and two of them had been treated with statins. None of the patients had malignant tumor, thyroid disease or acute infectious disease.

All patients gave their written consent before being enrolled in the study. The study was approved by the Human Ethical Committee, First Faculty of Medicine 
Table 1. Clinical characteristics of the cardiac surgery patients.

\begin{tabular}{lc} 
Number of subjects (male/female) & $10(6 / 4)$ \\
Body mass index $\left(\mathrm{kg} / \mathrm{m}^{2}\right)$ & $27 \pm 3$ \\
Age (years) & $56 \pm 14$ \\
Duration of the surgery (hours) & $4.6 \pm 1.2$ \\
Dyslipidemia & 5 \\
Arterial hypertension & 7 \\
Diabetes & 1 \\
\hline
\end{tabular}

Expressed as $n$ (number of patients) and mean \pm S.E.M.

and General University Hospital, Prague, Czech Republic and performed in accordance with the guidelines of the Helsinki declaration.

Anthropometric examination and blood and tissue
sampling

Anthropometric examination of the patients was performed at basal state one day before operation. All patients were measured and weighed and BMI was calculated.

Blood samples for the measurements of serum insulin levels and blood glucose were taken before the start of anesthesia and after the end of operation (at the time of admission to intensive care unit). Paired samples of the subcutaneous and epicardial adipose tissue were collected at the beginning and at the end of elective cardiac surgery from previously non-traumatized subcutaneous (thoracic region) and epicardial adipose tissue. Approximately $100 \mathrm{mg}$ of tissue was collected to $1 \mathrm{ml}$ of RNA stabilization Reagent (RNAlater, Qiagen, Germany) and stored at $-80^{\circ} \mathrm{C}$ until further analysis.

Blood glucose was measured on ABL 700 analyzer (Radiometer Medical A/S, Copenhagen, Denmark). Serum concentrations of insulin were measured using Human serum adipokine LINCOplex Kit (panel B) on Luminex ${ }^{\circledR} 200$ instrument (Linco Research, USA). Serum adiponectin concentrations were measured by commercial RIA kit (Linco Research, St. Charles, Missouri, USA).

\section{Determination of $m R N A$ expression}

Total RNA was extracted from subcutaneous and epicardial adipose tissue by homogenization on MagNA Lyser Instrument with MagNA Lyser Green Beads (Roche Diagnostics GmbH, Germany) using MagNA Pure Compact RNA Isolation (Tissue) (Roche Diagnostics GmbH, Germany). The RNA concentration was determined from absorbance at $260 \mathrm{~nm}$ (BioPhotometer, Eppendorf AG, Germany). All samples had a 260/280 nm absorbance ratio $1.89 \pm 0.1$. The integrity of the RNA was checked by visualization of $18 \mathrm{~S}$ and $28 \mathrm{~S}$ ribosomal bands on $1 \%$ agarose gel with an ethidium bromide. 0.1-1 $\mathrm{g}$ of total RNA was used for reverse transcription to synthesize the first strand cDNA using the oligo $(\mathrm{dT})_{18}$ primers following the instructions of the RevertAid First Strand cDNA synthesis kit (Fermentas Life Science, Lithuania). Gene expression of angiotensinogen, angiotensin-converting enzyme and angiotensin II type 1 receptor was performed on an ABI PRISM 7500 instrument (Applied Biosystems, Foster City, CA, USA) using TaqMan ${ }^{\circledR}$ Universal PCR Master Mix, NO AmpErase ${ }^{\circledR}$ UNG and specific TaqMan ${ }^{\circledR}$ Gene Expression Assays (Applied Biosystems, Foster City, CA, USA).

All PCRs for each gene were amplified separately. Controls with no template cDNA were performed with each assay and all samples were run at least in duplicates. The increase in fluorescence was measured in real time and data were obtained as threshold cycle $\left(\mathrm{C}_{\mathrm{T}}\right)$ values. To compensate for variations in input RNA amounts and efficiency of reverse transcription, beta-2-microglobulin was used as an endogenous reference and results were normalized to these values. Relative gene expression of genes was calculated using the formula $2^{-\Delta \Delta(\mathrm{CT} \text { cytokine-CT B2M) }}$.

\section{Statistical analysis}

The statistical analysis was performed on SigmaStat software (Jandel Scientific, USA). The results are expressed as means \pm S.E.M. Changes of gene expression during the cardiac surgery were evaluated using paired t-test. Results were considered statistical significant at $\mathrm{p}<0.05$.

\section{Results}

Both blood glucose and serum insulin levels significantly increased at the end of operation indicating the development of insulin resistance (Table 2). In contrast, serum adiponectin concentrations did not significantly change (Table 2).

At baseline, angiotensinogen (AGT), angiotensin-converting enzyme (ACE) and angiotensin II type 1 receptor (AGTR1) mRNA expression did not significantly differ between epicardial and subcutaneous adipose tissue depots (Table 2, Fig. 1). Expression of 
Table 2. Biochemical characteristics of the cardiac surgery patients and expression of angiotensinogen (AGT) mRNA, angiotensinconverting enzyme (ACE) mRNA and receptor for angiotensin II type 1 mRNA (normalized to B2M mRNA).

\begin{tabular}{lcc}
\hline & $\begin{array}{c}\text { Start } \\
\text { of operation }\end{array}$ & $\begin{array}{c}\text { End } \\
\text { of operation }\end{array}$ \\
\hline Blood glucose (mmol/l) & $5.9 \pm 1.1$ & $* 8.6 \pm 1.2$ \\
Serum insulin levels $(\mathrm{pg} / \mathrm{ml}$ ) & $130 \pm 36$ & $* 341 \pm 86$ \\
Serum adiponectin levels $(\mathrm{ng} / \mathrm{ml})$ & $17 \pm 8$ & $12 \pm 5$ \\
AGT mRNA in subcutaneous adipose tissue & $0.004 \pm 0.001$ & $0.002 \pm 0.0007$ \\
AGT mRNA in epicardial adipose tissue & $0.006 \pm 0.002$ & $* 0.011 \pm 0.002$ \\
ACE mRNA in subcutaneous adipose tissue & $0.011 \pm 0.002$ & $0.009 \pm 0.002$ \\
ACE mRNA in epicardial adipose tissue & $0.008 \pm 0.001$ & $0.007 \pm 0.001$ \\
Receptor for angiotensin II typ 1 mRNA in & $0.00008 \pm 0.00002$ & $0.00005 \pm 0.00001$ \\
subcutaneous adipose tissue & & $0.00004 \pm 0.00001$ \\
Receptor for angiotensin II typ 1 mRNA in & $0.00005 \pm 0.00001$ & \\
epicardial adipose tissue & & \\
\hline
\end{tabular}

Data are expressed as mean \pm S.E.M. Statistical significance is from paired T-test. * indicates $p<0.05$ vs. start of operation

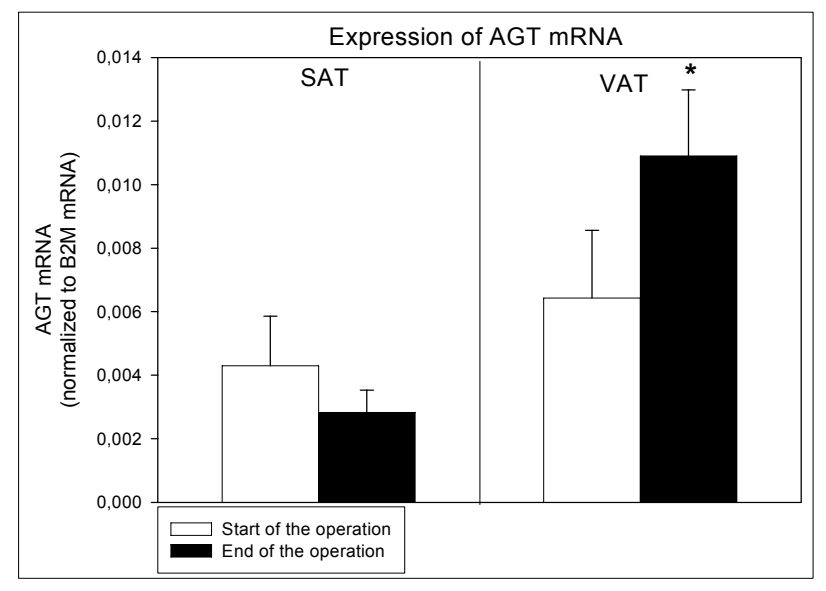

Fig. 1. Angiotensionogen (AGT) mRNA expression in subcutaneous (SAT) and epicardial adipose tissue (VAT) at the beginning (open bars) and at the end (black bars) of the surgery. Values are mean \pm S.E.M. Statistical significance is from paired t-test: $* p<0.05$ vs. VAT at the beginning of the surgery.

angiotensinogen mRNA in epicardial adipose tissue significantly increased at the end of the surgery compared to the baseline values, while no significant change of this parameter was found in subcutaneous adipose tissue (Table 2, Fig. 1). Neither subcutaneous nor epicardial angiotensin-converting enzyme and angiotensin II type 1 receptor mRNA expression were significantly affected by cardiac surgery (Table 2). We did not find any significant correlations between fat mRNA expression of angiotensinogen and blood glucose, serum insulin and serum adiponectin concentrations, respectively (data not shown).

\section{Discussion}

The aim of our study was to determine whether local production of renin-angiotensin system components in the adipose tissue contributes to the development of insulin resistance after cardiac operation. We have demonstrated that cardiac surgery significantly increased mRNA expression of angiotensinogen in epicardial adipose tissue suggesting its possible involvement in the induction of local and possibly systemic insulin resistance. Adipose tissue as a source of components of renin-angiotensin system has been identified previously (Engeli et al. 1999). However, it has not yet been described how the local renin-angiotensin system of the adipose tissue responds to a major stress. Here we have chosen patients undergoing elective cardiac surgery as a model for insulin resistance induced acutely by cardiac surgery. It has been shown previously that patients after major cardiac surgery develop insulin resistance also called ,diabetes of injury“ and that normalization of their blood glucose using intensive insulin therapy substantially decreased morbidity and mortality (van den Berghe et al. 2001). Despite marked progress in our understanding of the etiopathogenesis of this process the exact mechanism how the normalization of blood glucose improves the outcome of critically ill patients still remains to be elucidated.

The results of the present study confirm that all the main components of renin-angiotensin system (i.e. angiotensinogen, angiotensin-converting enzyme and 
angiotensin II type 1 receptor) are expressed in both subcutaneous and epicardial adipose tissue. Furthermore, we demonstrated that cardiac surgery increased expression of angiotensinogen mRNA in epicardial but not in subcutaneous adipose tissue. Overexpression of the components of renin-angiotensin system (angiotensinogen and angiotensin II type 1 receptor) in human visceral adipose tissue relative to subcutaneous adipose tissue in normal and overweight subjects has been previously reported by Giaccheti et al. (2002). In our study, we found an increase in angiotensinogen mRNA expression in epicardial adipose tissue in all patients independently of the previous treatment with angiotensinconverting enzyme blockers (ramipril) or statins which are both known for the beneficial effect on insulin sensitivity (Huptas et al. 2006, Ostergren 2007). Our data thus offer a novel insight on the adipose tissue function showing subcutaneous and visceral adipose tissues as two heterogeneous organs with different gene expression, proteins production and association with cardiovascular disease. This is in agreement with previously published studies showing different expression profiles in these two depots (Mazurek et al. 2003, Kershaw and Flier 2004).

Here we did not find any significant differences in expression of angiotensin-converting enzyme and angiotensin II type 1 receptor mRNA in adipose tissue during cardiac surgery and also no differences between subcutaneous and epicardial adipose tissue with respect to production of angiotensin-converting enzyme and angiotensin II type 1 receptor. This is in contrast with the study of Giacchetti et al. (2002) who showed that angiotensin II type 1 receptor expressed significantly more abundantly in visceral than in subcutaneous adipose tissue. However, it has to be noted that in our study we used different visceral adipose tissue depot (epicardial fat) and different subcutaneous adipose tissue depot (thoracic region fat).

In this study we did not evaluate the role of angiotensinogen produced by the adipose tissue on the systemic blood pressure in postoperative period, although this effect is traditionally the most important systemic effect of rennin-angiotensin system. We were not able to evaluate changes of the blood pressure because of the hemodynamic instability of cardiac surgery patients in a postoperative period and frequent need of pharmacological or mechanical support (e.g. catecholamines, intraaortic baloon pump etc.).

We suggest that increased expression of angiotensinogen leads in turn to enhanced production of angiotensin II in epicardial adipose tissue. Angiotensin II, a metabolically active hormone deriving from the cleavage of angiotensinogen, can then interfere with insulin signaling cascade (Ferder et al. 2006, Kurata et al. 2006). In summary, our data show that increased production of angiotensinogen in the epicardial adipose tissue may in concert with overproduction of other proinflammatory factors contribute to the development of insulin resistance in critically ill patients.

\section{Conflict of Interest}

There is no conflict of interest.

\section{Acknowledgements}

Supported in by MZOVFN2005 to M.H.

\section{References}

ANDERLOVÁ K, KŘEMEN J, DOLEŽALOVÁ R, HOUSOVÁ J, HALUZÍKOVÁ D, KUNEŠOVÁ M, HALUZíK $\mathrm{M}$ : The influence of very-low-calorie-diet on serum leptin, soluble leptin receptor, adiponectin and resistin levels in obese women. Physiol Res 55: 277-283, 2006.

BUTLER SO, BTAICHE IF, ALANIZ C: Relationship between hyperglycemia and infection in critically ill patients. Pharmacotherapy 25: 963-976, 2005.

COOPER ME: The role of the renin-angiotensin-aldosterone system in diabetes and its vascular complications. Am $J$ Hypertens 17: 16S-20S, quiz A2-4, 2004.

COOPER SA, WHALEY-CONNELL A, HABIBI J, WEI Y, LASTRA G, MANRIQUE CM, STAS S, SOWERS JR: Renin-angiotensin-aldosterone system and oxidative stress in cardiovascular insulin resistance. Am J Physiol 293: H2009-H2023, 2007.

DAHLOF B, DEVEREUX RB, KJELDSEN SE, JULIUS S, BEEVERS G, DE FAIRE U, FYHRQUIST F, IBSEN H, KRISTIANSSON K, LEDERBALLE-PEDERSEN O, LINDHOLM LH, NIEMINEN MS, OMVIK P, OPARIL S, WEDEL H: Cardiovascular morbidity and mortality in the Losartan Intervention For Endpoint reduction in hypertension study (LIFE): a randomised trial against atenolol. Lancet 359: 995-1003, 2002. 
ENGELI S, GORZELNIAK K, KREUTZ R, RUNKEL N, DISTLER A, SHARMA AM: Co-expression of reninangiotensin system genes in human adipose tissue. J Hypertens 17: 555-560, 1999.

ENGELI S, SCHLING P, GORZELNIAK K, BOSCHMANN M, JANKE J, AILHAUD G, TEBOUL M, MASSIERA F, SHARMA AM: The adipose-tissue renin-angiotensin-aldosterone system: role in the metabolic syndrome? Int J Biochem Cell Biol 35: 807-825, 2003.

FERDER L, INSERRA F, MARTINEZ-MALDONADO M: Inflammation and the metabolic syndrome: role of angiotensin II and oxidative stress. Curr Hypertens Rep 8: 191-198, 2006.

GANONG WF: Origin of the angiotensin II secreted by cells. Proc Soc Exp Biol Med 205: 213-219, 1994.

GIACCHETTI G, FALOIA E, MARINIELLO B, SARDU C, GATTI C, CAMILLONI MA, GUERRIERI M, MANTERO F: Overexpression of the renin-angiotensin system in human visceral adipose tissue in normal and overweight subjects. Am J Hypertens 15: 381-388, 2002.

HANSSON L, LINDHOLM LH, NISKANEN L, LANKE J, HEDNER T, NIKLASON A, LUOMANMAKI K, DAHLOF B, DE FAIRE U, MORLIN C, KARLBERG BE, WESTER PO, BJORCK JE: Effect of angiotensinconverting-enzyme inhibition compared with conventional therapy on cardiovascular morbidity and mortality in hypertension: the Captopril Prevention Project (CAPPP) randomised trial. Lancet 353: 611-616, 1999.

HOUSA D, HOUSOVÁ J, VERNEROVÁ Z, HALUZÍK M: Adipocytokines and cancer. Physiol Res 55: 233-244, 2006.

HOUSOVÁ J, KŘİŽOVÁ J, ANDERLOVÁ K, PAPEŽOVÁ H, HALUZÍK M: Serum concentrations of adiponectin in patients with restrictive and purgative subtype of mental anorexia. (in Czech) Cas Lek Cesk 144: 278-281, 2005.

HUPTAS S, GEISS HC, OTTO C, PARHOFER KG: Effect of atorvastatin $(10 \mathrm{mg} /$ day $)$ on glucose metabolism in patients with the metabolic syndrome. Am J Cardiol 98: 66-69, 2006.

IACOBELLIS G, SHARMA AM: Epicardial adipose tissue as new cardio-metabolic risk marker and potential therapeutic target in the metabolic syndrome. Curr Pharm Des 13: 2180-2184, 2007.

JONES BH, STANDRIDGE MK, TAYLOR JW, MOUSTAID N: Angiotensinogen gene expression in adipose tissue: analysis of obese models and hormonal and nutritional control. Am J Physiol 273: R236-R242, 1997.

KERSHAW EE, FLIER JS: Adipose tissue as an endocrine organ. J Clin Endocrinol Metab 89: 2548-2556, 2004.

KIM S, SOLTANI-BEJNOOD M, QUIGNARD-BOULANGE A, MASSIERA F, TEBOUL M, AILHAUD G, KIM JH, MOUSTAID-MOUSSA N, VOY BH: The adipose renin-angiotensin system modulates systemic markers of insulin sensitivity and activates the intrarenal renin-angiotensin system. J Biomed Biotechnol 2006: 27012, 2006.

KŘEMEN J, DOLÍNKOVÁ M, KRAJIĆCKOVÁ J, BLÁHA J, ANDERLOVÁ K, LACINOVÁ Z, HALUZÍKOVÁ D, BOŠANSKÁ L, VOKURKA M, SVAČINA S, HALUZÍK M: Increased subcutaneous and epicardial adipose tissue production of proinflammatory cytokines in cardiac surgery patients: possible role in postoperative insulin resistance. J Clin Endocrinol Metab 91: 4620-4627, 2006.

KRINSLEY JS: Association between hyperglycemia and increased hospital mortality in a heterogeneous population of critically ill patients. Mayo Clin Proc 78: 1471-1478, 2003.

KURATA A, NISHIZAWA H, KIHARA S, MAEDA N, SONODA M, OKADA T, OHASHI K, HIBUSE T, FUJITA K, YASUI A, HIUGE A, KUMADA M, KURIYAMA H, SHIMOMURA I, FUNAHASHI T: Blockade of Angiotensin II type-1 receptor reduces oxidative stress in adipose tissue and ameliorates adipocytokine dysregulation. Kidney Int 70: 1717-1724, 2006.

MAZUREK T, ZHANG L, ZALEWSKI A, MANNION JD, DIEHL JT, ARAFAT H, SAROV-BLAT L, O'BRIEN S, KEIPER EA, JOHNSON AG, MARTIN J, GOLDSTEIN BJ, SHI Y: Human epicardial adipose tissue is a source of inflammatory mediators. Circulation 108: 2460-2466, 2003.

MORIUCHI A, YAMASAKI H, SHIMAMURA M, KITA A, KUWAHARA H, FUJISHIMA K, SATOH T, FUKUSHIMA K, FUKUSHIMA T, HAYAKAWA T, MIZUGUCHI H, NAGAYAMA Y, ABIRU N, KAWASAKI E, EGUCHI K: Induction of human adiponectin gene transcription by telmisartan, angiotensin receptor blocker, independently on PPAR-gamma activation. Biochem Biophys Res Commun 356: 1024-1030, 2007. 
NYGREN J, THORELL A, EFENDIC S, NAIR KS, LJUNGQVIST O: Site of insulin resistance after surgery: the contribution of hypocaloric nutrition and bed rest. Clin Sci (Lond) 93: 137-146, 1997.

OSTERGREN J: Renin-angiotensin-system blockade in the prevention of diabetes. Diabetes Res Clin Pract 76: S13S21, 2007.

REID IA, MORRIS BJ, GANONG WF: The renin-angiotensin system. Annu Rev Physiol 40: 377-410, 1978.

SHANGRAW RE, JAHOOR F, MIYOSHI H, NEFF WA, STUART CA, HERNDON DN, WOLFE RR: Differentiation between septic and postburn insulin resistance. Metabolism 38: 983-989, 1989.

SCHEEN AJ: Prevention of type 2 diabetes mellitus through inhibition of the renin-angiotensin system. Drugs 64: 2537-2565, 2004.

VAN DEN BERGHE G: Novel insights into the neuroendocrinology of critical illness. Eur J Endocrinol 143: 1-13, 2000.

VAN DEN BERGHE G, WOUTERS P, WEEKERS F, VERWAEST C, BRUYNINCKX F, SCHETZ M, VLASSELAERS D, FERDINANDE P, LAUWERS P, BOUILLON R: Intensive insulin therapy in the critically ill patients. $N$ Engl J Med 345: 1359-1367, 2001.

VAN DEN BERGHE G, WILMER A, HERMANS G, MEERSSEMAN W, WOUTERS PJ, MILANTS I, VAN WIJNGAERDEN E, BOBBAERS H, BOUILLON R: Intensive insulin therapy in the medical ICU. $N$ Engl J Med 354: 449-461, 2006.

VANHOREBEEK I, LANGOUCHE L, VAN DEN BERGHE G: Glycemic and nonglycemic effects of insulin: how do they contribute to a better outcome of critical illness? Curr Opin Crit Care 11: 304-311, 2005.

VERMES E, DUCHARME A, BOURASSA MG, LESSARD M, WHITE M, TARDIF JC: Enalapril reduces the incidence of diabetes in patients with chronic heart failure: insight from the Studies Of Left Ventricular Dysfunction (SOLVD). Circulation 107: 1291-1296, 2003.

YUSUF S, SLEIGHT P, POGUE J, BOSCH J, DAVIES R, DAGENAIS G: Effects of an angiotensin-convertingenzyme inhibitor, ramipril, on cardiovascular events in high-risk patients. The Heart Outcomes Prevention Evaluation Study Investigators. N Engl J Med 342: 145-153, 2000. 